\title{
Hubungan antara Kepercayaan Diri dan Kecemasan Berkomunikasi pada
}

\section{Mahasiswa Ketika Presentasi}

\author{
Mega Kartikasari ${ }^{\mathrm{a} *}$, M. Noupal ${ }^{\mathrm{b}}$, and Kiki Cahaya Setiawan ${ }^{\mathrm{c}}$ \\ ${ }_{a, b, c}$ Universitas Islam Negeri Raden Fatah Palembang \\ *Corresponding author: kartikasarimega9@gmail.com
}

\begin{abstract}
Abstrak
Mahasiswa Prodi Biologi 2013 kurang percaya diri saat presentasi. Fokus penelitian ini adalah Korelasi Percaya Diri dengan Kecemasan Komunikasi Saat Presentasi Mahasiswa Fakultas Tarbiyah dan Guru Program Studi Biologi Garda 2013 UIN Raden Fatah Palembang. Jenis penelitian ini adalah kuantitatif korelasional. Hasil dari penelitian ini adalah terdapat hubungan positif yang signifikan antara kepercayaan diri dengan kecemasan komunikasi saat presentasi pada mahasiswa Fakultas Tarbiyah dan Guru Program Studi Biologi Garda 2013 Universitas Islam Negeri Raden Fatah Palembang. Selanjutnya sumbangan efektif yang diberikan oleh variabel kepercayaan terhadap kecemasan komunikasi saat presentasi pada mahasiswa Fakultas Tarbiyah dan Program Keguruan Angkatan 2013 Universitas Islam Negeri Fatah Palembang adalah sebesar $22,3 \%$ dan sisanya $77,7 \%$ dipengaruhi oleh faktor lain. yang tidak ada dalam penelitian ini.
\end{abstract}

\section{Kata Kunci}

Kepercayaan diri; Kecemasan komunikasi; Presentasi

\begin{abstract}
The 2013 Biology Study Program students lacked confidence during the presentation. The focus of this atudy is Correlations of Self Confidence with Anxiety Communication when Presentation of Students of Faculty Tarbiyah and Teacher Ship Program Study Biology Guard 2013 State Islamic University Raden Fatah Palembang. This research is quantitative correlational. The results of this study is there is a significant positive correlations of selfconfidence with communication anxiety when presentation on the students of Faculty of Tarbiyah and Teacher Ship Program Study Biology Guard 2013 State Islamic University Raden Fatah Palembang. Furthermore, the effective contribution given by the confidence variable to communication anxiety during the presentation on the students of Faculty of Tarbiyah and Teacher Ship Program of 2013 Class of Universitas State Islamic University Fatah Palembang is $22.3 \%$ and the rest $77.7 \%$ is influenced by other factors that are not in this research.
\end{abstract}

Keywords

Self Confidence; Anxiety Communication; Presentation 


\section{Pendahuluan}

$\mathrm{P}$ endidikan merupakan kunci bagi suatu bangsa untuk bisa menyiapkan masa depan dan sanggup bersaing dengan bangsa lain. Dunia pendidikan dituntut memberikan respon lebih cermat terhadap perubahan-perubahan yang tengah berlangsung di masyarakat. Menurut Undang-Undang RI No. 20 Tahun 2003 tentang sistem pendidikan nasional Bab I Pasal I mendefinisikan pendidikan sebagai usaha sadar dan terencana untuk mewujudkan suasana belajar dan proses belajar agar peserta didik secara aktif mengembangkan potensi dirinya untuk memiliki kekuatan spiritual keagamaan, pengendalian diri, kepribadian, kecerdasan, akhlak mulia serta keterampilan yang diperlukan dirinya, masyarakat, bangsa dan Negara.

Pendidikan dasar berbentuk sekolah dasar (SD) dan madrasah ibtidaiyah (MI) atau bentuk lain yang sederajat serta sekolah menengah pertama (SMP) dan madrasah tsanawiyah (MTS). Pendidikan menengah berbentuk sekolah menengah atas (SMA), madrasah aliyah (MA). Sekolah menengah kejuruan (SMK), dan madrasah aliyah kejuruan (MAK). Pendidikan tinggi merupakan jenjang pendidikan setelah pendidikan menengah mencakup program pendidikan diploma, sarjana, magister, spesialis, dan doktor yang diselenggarakan oleh pendidikan tinggi. Pendidikan tinggi diselengarakan dengan sistem terbuka. Perguruan tinggi dapat berbentuk akademi, politik, sekolah tinggi, institut, atau universitas.

Universitas menurut Wikipedia adalah suatu institusi pendidikan tinggi dan penelitian, yang memberikan gelar akademik dalam berbagai bidang. Universitas Islam Negeri (UIN) Raden Fatah terdiri dari 6 Fakultas yang masingmasing memiliki beragam spesifikasi pendidikan antara lain. Fakultas Syari'ah dan Hukum, Fakultas Tarbiyah dan Keguruan, Fakultas Ushuluddin dan Pemikiran Islam, Fakultas Adab dan Humaniora, Fakultas Dakwah dan Komunikasi, Fakultas Ekonomi dan Bisnis Islam. Pada penelitian ini peneliti fokus pada Mahasiswa Fakultas Tarbiyah dan Keguruan Program Studi Biologi karena sebagai seorang calon guru Mahasiswa Fakultas Tarbiyah dan Keguruan Program Studi Biologi dituntut untuk mempunyai kemampuan berbicara di depan umum namun pada kenyataanya masih banyak mahasiswa yang mengalami kecemasan komunikasi.

Kecemasan merupakan pengalaman yang tidak menyenangkan mengenai kekhawatiran atau ketegangan berupa perasaan cemas. Individu yang mengalami kecemasan dipengaruhi oleh beberapa hal, di antaranya karena adanya pengalaman negatif perilaku yang telah dilakukan, seperti kekhawatiran akan adanya kegagalan. Menurut Rakhmat ketakutan untuk melakukan komunikasi dikenal sebagai communication apprehension. Orang yang aprehensif dalam komunikasi, akan menarik diri dari pergaulan, berusaha sekecil mungkin berkomunikasi, dan hanya akan berbicara apabila terdesak saja. Rakmat menyatakan tidak semua aprehensi komunikasi disebabkan kurangnya percaya diri tetapi di antara berbagai faktor, percaya diri adalah yang paling menentukan.

Seperti yang terjadi pada mahasiswa Fakultas Tarbiyah dan Keguruan Program 
Studi Biologi angkatan 2013 Universitas Islam Negeri Raden Fatah Palembang. Mahasiswa yang mengalami kecemasan dalam berkomunikasi tersebut terjadi ketika dalam situasi diskusi atau menyampaikan isi makalahnya di depan dosen dan temanteman. Salah satu yang menjadi penyebab terjadinya kesulitan komunikasi adalah adanya kecemasan rasa takut menerima tanggapan atau penilaian negatif dari komunikan atau orang yang menerima pesan. Mahasiswa Fakultas Tarbiyah dan keguruan Program Studi Biologi terdiri dari 4 angkatan yaitu, angkatan 2012, 2013, 2014, dan 2015.

Dalam penelitian ini peneliti fokus pada mahasiswa angkatan 2013 yang masih aktif karena pengalaman mahasiswa berbicara di depan kelas saat presentasi sudah semakin banyak. Selain itu mahasiswa angkatan 2013 umunya berumur antara 19-21 tahun yang mengalami peralihan dari remaja akhir ke dewasa awal. beberapa mahasiswa yang merasa gugup ketika menjawab pertanyaan yang diberikan pada saat presentasi kelompok dikarenakan menurut mereka merasa takut jawaban yang akan dijelaskan tidak dimengerti oleh temanteman yang lain, takut salah menjawab pertanyaan, malu dilihat teman-teman, serta tidak siap dan kurang menguasai materi. Beberapa mahasiswa juga mengungkapkan berbicara terbata-bata ketika menjelaskan pada saat presentasi dikarenakan merasa kurang percaya diri pada saat menjelaskan hal tersebut, selain itu beberapa mahasiswa sebelum presentasi tidak belajar dengan serius.

Beberapa mahasiswa juga mengatakan merasa cemas ketika menunggu giliran untuk berbicara di depan kelas saat presentasi dikarenakan ada beberapa dari mereka yang tidak suka menjadi pusat perhatian, demam panggung, gugup, degdegan, gemetaran, takut akan terjadi kesalahan, karena melihat presentasi kelompok sebelumnya. Beberapa mahasiswa juga mengatakan merasa diri tidak berguna apabila tidak dapat menjawab pertanyaan pada saat presentasi. Selain itu, beberapa mahasiswa juga mengungkapkan tiba-tiba pikirannya menjadi kosong apabila berbicara pada saat presentasi dikarenakan tidak konsentrasi dengan materi yang dipresentasikan, merasa grogi saat semua teman tertuju kepadanya, gampang lupa, bahkan ada juga beberapa mahasiswa yang sering melamun pada saat presentasi. Selain itu, beberapa mahasiswa merasa panik apabila menjawab pertanyaan yang tidak di pahami dikarenakan bingung untuk menjawab pertanyaan yang tidak dimengerti, selain itu ada beberapa mahasiswa merasa malu kepada dosen dan teman-teman jika bisa menjawab pertanyaan yang tidak di pahami.

Beberapa mahasiswa merasa pikirannya menjadi kacau pada saat teman kelompok lain banyak bertanya dikarenakan menurut beberapa mahasiswa tidak mengetahui pertanyaan-pertanyaan yang ditujuh apakah mudah atau sulit, bisa menjawab atau tidak, selain itu beberapa mahasiswa merasa takut jika ada salah satu pertanyaan tidak terjawab, kemudian beberapa mahasiswa bingung karena banyak pertanyaan yang harus dijawab, selain itu pertanyaan akan berputar dan terkadang jawaban yang telah ada menghilang dari otak. Bahkan beberapa mahasiswa mengalami sulit tidur apabila besok maju presentasi kelompok dikarenakan takut apa yang disampaikan nanti teman-teman tidak paham, khawatir 
dan kepikiran melakukan kesalahan saat presentasi keesokan harinya.

Mereka mengalami kecemasan dan takut membuat kesalahan jika harus berbicara di depan kelas terutama pada saat mempresentasikan makalah, mempresentasikan tugas. Beberapa mahasiswa juga mengungkapkan saat mendapatkan giliran mempresentasikan makalah merasa berkeringat dingin dikarenakan merasa semua mata tertuju kepadanya. begitu juga Pada saat membacakan materi beberapa mahasiswa tangannya gemetaran dikarenakan cemas.

Menurut pendapat Enung kepercayaan diri adalah sikap positif seorang individu yang memampukan dirinya untuk mengembangkan penilaian positif, baik terhadap diri sendiri maupun terhadap lingkungan/situasi yang dihadapi. Orang yang kurang percaya diri akan terlihat dari sikap dan tindakan. Misalnya, tidak yakin pada diri sendiri, selalu bergantung pada orang lain, dan tidak berani menggambil keputusan. Beberapa mahasiswa yang tidak memiliki keyakinan yang kuat untuk mempresntasikan makalah dengan baik dikarenakan menurut beberapa mahasiswa tidak suka diperhatikan dan belum memahami makalah yang akan disampaikan.

Beberapa mahasiswa juga merasa tidak yakin dapat menjawab pertanyaan yang diberikan pada saat presentasi dikarenakan ada perasaan takut salah menjawab terkadang ada juga pertanyaan yang di luar dari pembahasan. Beberapa mahasiswa juga sering melakukan protes apabila mendapat nilai yang tidak memuaskan karena merasa sudah belajar sunguhsungguh tapi hasilnya tetap saja kecil.
Selain itu ada mahasiswa yang tidak senang jika ada masukkan dari teman kelompok karena masalah yang dikritik tidak membangun. Beberapa mahasiswa juga sering mengabaikan tugas yang diberikan dosen dikarenakan tugas yang begitu banyak dan merasa tidak mampu untuk mengerjakannya.

\section{Metode}

\section{Partisipan}

1. Populasi

Populasi pada penelitian ini adalah seluruh mahasiswa Fakultas Tarbiyah dan Keguruan Program Studi Biologi angkatan 2013 Universitas Islam Negeri Raden Fatah Palembang yang berjumlah 110 mahasiswa.

\section{Sampel}

Menurut Azwar, sampel adalah sebagian dari populasi. Karena sampel merupakan bagian dari populasi, tentulah harus memiliki ciri-ciri yang dimiliki oleh populasinya. Sementara itu menurut Arikunto sampel adalah sebagian atau wakil populasi yang diteliti. Sedangkan sampel dalam penelitian ini diambil dengan melihat tabel pengambilan sampel yang dikembangkan oleh Isaac dan Michael. Pada jenjang 110 dengan taraf 5\% kesalahan yaitu 84 orang yang tercatat aktif sebagai mahasiswa Fakultas Tarbiyah dan Keguruan Program Studi Biologi angkatan 2013 Universitas Islam Negeri Raden Fatah Palembang.

Teknik pengambilan sampel dalam penelitian ini menggunakan teknik simple random sampling, Adapun proses pengambilan data penelitian, peneliti membagi sampel menjadi dua kelompok 
yang terdiri dari kelompok uji coba (Try Out) dan kelompok penelitian.

\section{Prosedur}

Metode dalam penelitian ini menggunakan metode kuantitatif yaitu penelitian yang menggunakan angka, yang datanya berwujud bilangan (skor atau nilai, peringkat, dan frekuensi) yang dianalisis dengan menggunakan statistik untuk menjawab pertanyaan atau hipotesis yang sifatnya spesifik, dan untuk melakukan prediksi bahwa suatu variabel tertentu mempengaruhi variabel yang lain.

\section{Alat Ukur}

Alat pengumpulan data yang digunakan dalam penelitian ini adalah skala. Jenis skala yang digunakan adalah Skala Likert. Skala yang digunakan dalam penelitian ini terdiri dari.

1. Skala Kecemasan Komunikasi Saat Presentasi

Skala kecemasan diukur dengan menggunakan jenis skala likert untuk objek sikap berupa pernyataan-pernyataan. Skala kecemasan komunikasi saat presentasi terdiri dari 60 item pernyataan. Pada skala likert terdapat 4 alternatif jawaban, yaitu SS (sangat setuju), S (Setuju), TS (tidak setuju), STS (Sangat Tidak Setuju).

\section{Skala Kepercayaan Diri}

Skala kepercayaan diri diukur dengan menggunakan jenis skala Likert berupa pernyataan-pernyataan. Skala kepercayaan diri terdiri dari 60 item pernyataanpernyataan. Penyusunan skala tersebut berdasarkan aspek-aspek Kepercayaan Diri dari Lauster. Pada skala likert terdapat 4 alternatif jawaban, yaitu SS (sangat setuju),
S (Setuju), TS (tidak setuju), STS (Sangat Tidak Setuju).

\section{Analisis Data}

1. Uji Normalitas

Uji normalitas sebaran digunakan untuk mengetahui apakah data yang digunakan dalam penelitian ini berdistribusi normal atau tidak. Kaidah yang digunakan untuk mengetahui normalitas sebaran data adalah jika $\mathrm{p}<0,05$ sebaran dinyatakan normal, dan jika $p>0,05$ maka sebaran dinyatakan tidak normal.

\section{Uji Linieritas}

Uji linieritas dilakukan untuk mengetahui hubungan antara variabel bebas yakni kepercayaan diri dengan variabel terikat yakni kecemasan komunikasi saat presentasi. Hubungan antara variabel bebas dan terikat dikatakan linier jika ditemukan penyimpangan. Kaidah yang digunakan adalah jika $\mathrm{p}<0,05$ maka hubungan antara variabel bebas dan terikat dinyatakan linier dan jika $\mathrm{p}>0,05$ maka hubungan tidak linier.

\section{Uji Hipotesis}

Setelah uji normalitas dan uji linieritas terpenuhi, kemudian dilakukan uji hipotesis. Perhitungan yang digunakan dalam penelitian ini adalah menggunakan teknik analisis regresi sederhana (simple regression) yaitu untuk mengetahui bentuk hubungan antara satu variabel bebas dan satu variabel terikat. Dengan tujuan untuk membuat perkiraan (prediksi) hubungan antara kepercayaan diri dengan kecemasan komunikasi saat presentasi dan digunakan untuk memprediksikan seberapa jauh perubahan nilai variabel dependen, bila nilai variabel independen dimanipulasi/dirubah-rubah atau dinaik 
turunkan. Adapun semua analisis penelitian ini menggunakan bantuan program komputer program statistik SPSS (Statistical Package for Sosial Science) versi 23.00 for windows.

Adapun kaidah yang digunakan dalam uji hipotesis adalah nilai taraf signifikansi 0,05 dimana $\mathrm{p} \leq 0,05$ maka Ho ditolak dan $\mathrm{Ha}$ diterima dengan implikasi terhadap hipotesis adalah signifikan. Sedangkan pada taraf signifikansi $\mathrm{p}>0,05$ maka Ho diterima dan Ha ditolak dengan implikasi terhadap hipotesis tidak signifikan.

\section{Hasil}

\section{Uji Normalitas}

Uji normalitas dilakukan untuk mengetahui normalitas sebaran data penelitian, yaitu jika taraf signifikan lebih dari 0,05 ( $\mathrm{p}>$ $0,05)$ berarti data berdistribusi normal. Sebaliknya, jika taraf signifikan kurang dari $0,05(\mathrm{p}<0,05)$, maka data berdistribusikan tidak normal.

\section{Uji Linieritas}

Kaidah uji yang digunakan adalah "jika $\mathrm{p}<$ 0,05, maka hubungan antara variabel bebas (X) dan variabel terikat (Y) dinyatakan linier. Sebaliknya, jika $\mathrm{p}>0,05$, maka hubungan antara variabel bebas (X) dan variabel terikat (Y) dinyatakan tidak linier".

\section{Uji Hipotesis}

Hasil uji hipotesis antara kedua variabel tersebut dapat dilihat pada tabel 3 . Berdasarkan analisis yang telah peneliti lakukan sebelumnya, diperoleh hasil yang menunjukan bahwa adanya hubungan yang signifikan antara kepercayaan diri dengan kecemasan komunikasi saat presentasi, dan koefisien korelasi sebesar $0,473(\mathrm{R}=0,473)$ dengan nilai signifikansi sebesar 0,000 dimana $\mathrm{p}<0,05$. Hasil uji statistik menunjukkan bahwa nilai $\mathrm{R}$ square sebesar 0,223, yang berarti kepercayaan diri memiliki peranan terhadap kecemasan komunikasi saat presentasi sebesar 22,3\%.

Tabel 1.

Deskripsi Hasil Uji Normalitas

\begin{tabular}{lccl}
\multicolumn{1}{c}{ Variabel } & K-S Z & Sig. & \multicolumn{1}{c}{ Ket. } \\
\hline $\begin{array}{l}\text { Kepercayaan } \\
\text { Diri }\end{array}$ & 1,147 & 0,144 & $\begin{array}{l}\text { Berdistribusi } \\
\text { Normal }\end{array}$ \\
\hline Kecemasan & 1,538 & 0,18 & Berdistribusi \\
Komunikasi & & & Normal \\
Saat & & & \\
Presentasi & & & \\
\hline
\end{tabular}

Tabel 2.

Deskipsi Hasil Uji Linieritas

$\begin{array}{llll}\text { Variabel } & \text { F } & \text { Sig }\end{array}$

Kepercayaan Diri $><\quad 23,579 \quad 0,00 \quad$ Linier

Kecemasan

Komunikasi Saat

Presentasi

Tabel 3.

Deskripsi Hasil Uji Hipotesis

\begin{tabular}{ccccc}
\hline Variabel & $\mathbf{R}$ & $\begin{array}{c}\text { R } \\
\text { Square }\end{array}$ & $\begin{array}{c}\text { Sig. } \\
(\mathbf{p})\end{array}$ & Ket. \\
\hline $\begin{array}{c}\text { Kepercayaan } \\
\text { Diri }\end{array}$ & 0,473 & 0,223 & 0,000 & Sig. \\
$\Leftrightarrow$ Kecemasan & & & & \\
$\begin{array}{c}\text { Komunikasi } \\
\text { Saat }\end{array}$ & & & & \\
Presentasi & & & & \\
\hline
\end{tabular}

\section{Diskusi}

Penelitian ini menggunakan analisis regression sederhana yang digunakan untuk menentukan hubungan antara dua variabel penelitian, yaitu variabel kepercayaan diri dengan kecemasan komunikasi saat presentasi pada mahasiswa 
Fakultas Tarbiyah dan Keguruan Program Studi Biologi angkatan 2013 Universitas Negeri Raden Fatah Palembang. Berdasarkan hasil uji hipotesis, tampak ada hubungan positif antara kepercayaan diri dengan kecemasan komunikasi saat presentasi pada mahasiswa Fakultas Tarbiyah dan Keguruan Program Studi Biologi angkatan 2013 Universitas Islam Negeri Raden Fatah Palembang. Hal ini dapat diketahui dari analisis data yang digunakan untuk menguji hipotesis koefisien korelasi menunjukkan nilai sebesar 0,473 dengan nilai signifikansi (p) sebesar 0,000 atau $\mathrm{p}<0,05$.

Sehingga dapat diketahui bahwa ada hubungan positif signifikan antara kepercayaan diri dengan kecemasan komunikasi saat presentasi pada mahasiswa Fakultas Tarbiyah dan Keguruan Program Studi Biologi angkatan 2013 Universitas Islam Negeri Raden Fatah Palembang. Artinya semakin tinggi tingkat kepercayaan diri yang dimiliki seseorang maka akan semakin tinggi tingkat kecemasan komunikasi orang tersebut. Sebaliknya seseorang yang memiliki tingkat kepercayaan diri yang relatif rendah maka kecemasan komunikasinya rendah.

Penelitian ini selaras dengan penelitian sebelumnya yang dilakukan oleh Riza Rahayu yang merupakan mahasiswa Fakultas Psikologi Universitas Muhammadiyah Aceh, yang berjudul "Hubungan Antara Kepercayaan Diri dengan Kecemasan Komunikasi Interpersonal Pada Mahasiswa Fakultas Kesehatan Masyarakat Universitas Muhammadiyah Aceh di Banda Aceh" pada tahun 2012. Hasil analisis data pada penelitian ini didapat nilai r sebesar 0,363 dan signifikansi $\mathrm{P}=0,009(\mathrm{P}<0,01)$ penelitian ini menunjukkan bahwa adanya hubungan positif yang signifikan antara kepercayaan diri dan kecemasan komunikasi interpersonal. Artinya semakin tinggi kepercayaan diri seseorang maka semakin tinggi kecemasan komunikasi interpersonal pada diri seseorang, begitu juga sebaliknya.

Penelitian lain yang turut mendukung yang dilakukan oleh Robi'atul Adawiyah yang merupakan mahasiswa Program Studi Psikologi Fakultas Ilmu Sosial dan Humaniora Universitas Islam Negeri Sunan Kalijaga Yogyakarta mengenai "Hubungan Antara Konsep Diri Dan Kecemasan Komunikasi Pada Mahasiswa Psikologi UIN Suka Yogyakarta” Berdasarkan hasil analisis menunjukkan bahwa koefisien hubungan $r=0,162$ dengan $p=0,108(P>$ 0,05). Penelitian ini menunjukkan bahwa tidak ada hubungan yang singnifikan antara konsep diri dengan kecemasan komunikasi pada mahasiswa semester 3 program Psikologi UIN Sunan Kalijaga. Artinya hipotesis yang diajukan sebelumnya ditolak. Sumbangan konsep diri terhadap kecemasan komunikasi sebesar 2,6\%.

Mc Croskey menyatakan bahwa dalam perilaku komunikasi seseorang tidak hanya dipengaruhi oleh kepercayaan diri namun juga dipengaruhi oleh pengetahuan seseorang terhadap topik yang akan dibawakan, rasa suka atau tidak suka terhadap topik tersebut dan psikomotorik seseorang yaitu kemampuan fisik seseorang untuk melakukan komunikasi. Bila seseorang menguasai topik yang dikomunikasikan maka orang tersebut tidak akan mengalami hambatan dalam berkomunikasi, begitu juga apabila seseorang menyukai topik yang akan dibawakan maka dia tidak akan mengalami 
hambatan dalam berkomunikasi. Sebaliknya bila seseorang tidak menguasai dan tidak menyukai topik yang dikomunikasikan, maka kecemasan atau communication apprehension seseorang akan meningkat.

Menurut M. Nur Ghufron dan Rini Risnawati kecemasan adalah suatu keadaan tertentu (state anxiety), yaitu menghadapi situasi yang tidak pasti dan tidak menentu terhadap kemampuannya dalam menghadapi objek tersebut. Hal tersebut berupa emosi yang kurang menyenangkan yang dialami oleh individu dan bukan kecemasan sebagai sifat yang melekat pada kepribadian. Individu yang mengalami kecemasan dipengaruhi oleh beberapa hal, di antaranya karena adanya pengalaman negatif perilaku yang telah dilakukan, seperti kekhawatiran akan adanya kegagalan. ${ }^{1}$ Menurut Rakhmat ketakutan untuk melakukan komunikasi dikenal sebagai communication apprehension. Orang yang aprehensif dalam komunikasi, akan menarik diri dari pergaulan, berusaha sekecil mungkin berkomunikasi, dan hanya akan berbicara apabila terdesak saja. Rakmat menyatakan tidak semua aprehensi komunikasi disebabkan kurangnya percaya diri tetapi di antara berbagai faktor, percaya diri adalah yang paling menentukan.

Dalam pandangan Islam yang menjelaskan tentang kecemasan atau rasa takut dari seseorang tersebut adalah hal wajar dimana orang yang sehat rohaninya, terlihat ketenangan pada mukanya, sebaliknya orang yang mengalami gangguan penyakit rohani, terungkap pula melalui kegelisahan. Daradjat menyatakan bahwa kecemasan dalam diri individu ternyata dapat menimbulkan reaksi-reaksi tertentu dan masing-masing individu akan memberikan yang berbeda satu sama lain. Hal ini sering muncul ketika seseorang menghadapi persoalan berat atau situasi yang menegangkan sehingga menimbulkan kegelisahan, kepanikan, dan kebingungan. Sebagaimana yang dijelaskan Allah Swt dalam Q.S As-Syu'ara: 12-14 yaitu.

Artinya:"Dia (Musa) berkata, "Ya
Tuhanku sungguh, aku takut
mereka akan mendustakan aku,
Sehingga dadaku terasa sempit
dan lidahku tidak lancar, maka
utuslah Harun (bersamaku),
Sebab aku berdosa terhadap
mereka, maka aku takut mereka
akan membunuhku." (Q.S As-
Syu'ara: 12-14)

Ayat diatas menjelaskan bahwa seseorang akan mengalami kecemasan yang meliputi rasa takut, kekhawatiran apabila melakukan sebuah kesalahan dan tidak sesuai dengan keadaan. Dalam teori kecemasan segala bentuk situasi yang mengancam kesejahteraan organisme dapat menimbulkan kecemasan dimana konflik merupakan salah satu sumber munculnya rasa cemas, adanya ancaman fisik, ancaman terhadap harga diri, serta perasaan tertekan untuk melakukan sesuatu di luar kemampuan serta menumbuhkan kecemasan.

Menurut Fatimah, Kepercayaan diri adalah sikap positif seorang individu yang memampukan dirinya untuk mengembangkan penilaian positif, baik

\footnotetext{
${ }^{1}$ Gufron \& Risnawita, Teori-Teori Psikologi..., hlm. 145
} 
terhadap diri sendiri maupun terhadap lingkungan atau situasi yang dihadapainya. Sebagaimana firman Allah yang berbunyi: Artinya : Sesungguhnya orang-orang yang mengatakan: "Tuhan Kami ialah Allah" kemudian mereka meneguhkan pendirian mereka, maka malaikat akan turun kepada mereka (dengan mengatakan): "Janganlah kamu takut dan janganlah merasa sedih; dan bergembiralah kamu dengan (memperoleh) surga yang telah dijanjikan Allah kepadamu". (QS. Fusshilat: 30)

Ayat di atas menjelaskan tentang percaya diri karena berkaitan dengan sifat dan sikap seorang mukmin yang memiliki nilai positif terhadap dirinya dan memiliki keyakinan yang kuat. Ayat di atas nampak bahwa orang yang percaya diri dalam al-Qur'an disebut sebagai orang yang tidak takut dan sedih serta tidak mengalami kegelisahan adalah orang-orang yang beriman dan orang-orang yang istiqamah.

Selayaknya manusia yang tidak sempurna, penelitian ini tidak luput dari kelemahankelemahan. Pertama, subjek penelitian memiliki kepercayaan diri tidak terlalu tinggi sebagaimana dalam hasil penelitian di atas yang hasil terbanyak menunjukkan kategori sedang. Hal ini dapat disebabkan karena pada saat pengisian skala, subjek penelitian merespon skala tersebut kurang sesuai dengan kondisi sebenarnya melainkan merespon secara normatif. Sehingga sebagian besar mahasiswa yang menjadi subjek penelitian memiliki kategori yang sedang saja. Kedua hal tersebut menunjukkan bahwa kepercayaan diri tidak mutlak sebagai suatu yang menyebabkan kecemasan komuniksi saat presentasi, karena sumbangan kepercayaan diri terhadap kecemasan komunikasi saat presentasi dalam penelitian ini hanya $22,3 \%$. Ketiga, waktu pelaksanaan pengambilan data penelitian bersamaan dengan waktu mahasiswa melaksanakan ujian akhir semester (UAS) sehingga peneliti tidak dapat mengkondisikan waktu pengerjaan pengambilan data penelitian dilakukan secara serentak.

\section{Kesimpulan}

Berdasarkan hasil analisis dan pembahasan yang diperoleh maka penulis menyimpulkan bahwa hasil penelitian adalah adanya hubungan positif yang signifikan antara kepercayaan diri dengan kecemasan komunikasi saat presentasi pada mahasiswa Fakultas Tarbiyah dan Keguruan Program Studi Biologi angkatan 2013 Universitas Islam Negeri Raden Fatah Palembang. Selanjutnya besarnya sumbangan efektif yang diberikan oleh variabel kepercayaan diri terhadap kecemasan komunikasi saat presentasi pada mahasiswa Fakultas Tarbiyah dan Keguruan Program Studi Biologi angkatan 2013 Universitas Islam Negeri Raden Fatah Palembang adalah sebesar 22,3\% dan selebihnya $77,7 \%$ dipengaruhi oleh faktor lain yang tidak ada dalam penelitian ini.

Berdasarkan temuan peneliti setelah melakukan penelitian dan melakukan hasil analisis penelitian, maka peneliti mengajukan beberapa saran terhadap pihak-pihak yang terkait, sebagai berikut:

\section{Bagi Subjek Penelitian}

Bagi mahasiswa Fakultas Tarbiyah dan Keguruan Program Studi Biologi angktan 2013 Universitas Islam Negeri Raden Fatah Palembang yang memiliki kategori 
kecemasan komunikasi sedang, diharapkan dapat mengurangi kecemasan komunikasi. Seperti lebih aktif dalam berinteraksi sosial, sering berlatih dalam berkomunikasi secara ilmiah atau formal dalam menyampaikan informasi di depan dosen dan teman-teman.

\section{Bagi mahasiswa}

Bagi mahasiswa diharapkan dapat meningkatkan kepercayaan diri dengan yakin terhadap diri, dapat bertindak mandiri, serta memiliki penilaian yang positif terhadap diri sendiri, karena dengan berbekal pada kepercayaan diri maka dapat membantu mahasiswa dalam berkomunikasi pada saat presentasi tanpa merasa khawatir tentang sesuatu hal yang menimbulkan kecemasan dalam berkomunikasi pada saat presentasi.

\section{Bagi peneliti selanjutnya}

Bagi peneliti selanjutnya disarankan dapat melakukan penelitian dengan jumlah subjek yang lebih banyak dan menyeluruh. Serta dapat memilih waktu penelitian pada waktu yang tepat sehingga subjek tidak memilki kesibukan seperti sedang kuliah yang dapat mempengaruhi respon subjek ketika mengisi instrumen penelitian. Selain itu, bagi penelitian selanjutnya yang ingin mengkaji variabel terikat yang sama untuk mempertimbangkan faktor lain sebagai variabel bebas yang mungkin memiliki hubungan dengan variabel kecemasan komunikasi saat presentasi.

\section{Referensi}

Adawiyah, R. (2012). Hubungan Antara Konsep Diri Dengan Kecemasan Komunikasi Pada Mahasiswa Psikologi UIN Suka Yogyakarta, Skripsi, Fakultas Ilmu Sosial dan Humaniora Universitas Sunan Kalijaga Yogyakarta.
Anwar, A. I. D. (2009). Hubungan Antara Self Efficacy Dengan Kecemasan Berbicara Di Depan Umum Pada Mahasiswa Fakultas Psikologi Universitas Sumatera Utara, Skripsi, Fakultas Psikologi Universitas Sumatera Utara.

Arikunto, S. (2006). Prosedur Penelitian. Jakarta: Rineka Cipta.

Atkinson. (1996). Pengantar Psikologi Terjemahan Kusuma W. Jakarta: Erlangga.

Azwar, S. (2010). Metode Penelitian. Yogyakarta: Pustaka Pelajar.

Azwar, S. (2013). Penyusunan Skala Psikologi. Yogyakarta: Pustaka Pelajar.

Azwar, S. (2011). Tes Prestasi, Fungsi dan Pengambangan Pengukuran Prestasi Belajar. Yogyakarta: Pustaka Pelajar.

Burhanuddin, Y. (1999). Kesehatan Mental Untuk Fakultas Tarbiyah Komponen Mkk. Bandung: CV Pustaka Setia.

Cahplin, J. P. (2009). Kamus Lengkap Psikologi, Jakarta: PT Raja Grafindo Persada.

Daradjat, Z. (1892). Peranan Agama Dalam Kesehatan Mental. Jakarta: PT Gunung Agung.

Devito, J.A, Komunikasi Antar Manusia (adisi kelima) Terjemahan, Jakarta, Kharisma Publishing Group, 2011

Dewi, P. A., \& Andrianto, S. (2006). Hubungan Antara Pola Pikir Dengan Kecemasan Berbicara Di Depan Umum Pada Mahasiswa Fakultas Keguruan Dan Ilmu Pendidikan Universitas Muhammadiyah Purwokerto Angkatan 2003, Skripsi, Fakultas Psikologi dan Sosial Budaya Universitas Islam Indonesia Yogyakarta.

Fatimah, E. (2008). Psikologi Perkembangan. Bandung: CV Pustaka Setia. 
Feist, J. \& Feist, G. J. (2010). Teori Kepribadian. Jakarta: Salemba Humaika.

Fektori, R. (2015). Trik-Trik Komunikasi Untung Mempengaruhi Orang Lain. Yogyakarta: Notebook.

Gufron, M. Nur \& Risnawita (2010). TeoriTeori Psikologi. Yogyakarta: ArtRuzz Media.

Hakim, T. (2005). Mengatasi Rasa Tidak Percaya Diri. Jakarta: Puspa Swara.

http://www.populer.web.id/2015/02/penda ftaran-online-universitas.html di akses pada tanggal 23 November 2015 Pukul 08:30 wib

http://www/berkuliah.com./2014/08/profiliain-raden-fatah-palembang.html di akses pada tanggal 23 November 2015 Pukul 08:27 wib

Kasir I. M. (n.d.). Kamus Arab-Indonesia Indonesia-Arab, Surabaya, Apollo, t.h

Kementerian Agama RI. (2012). Al-Qur'an Terjemah. Jakarta: Kementerian Agama RI.

Khayyirah, B. (2013). Cara Pintar Berbicara Cerdas Di Depan Publik. Yogyakarta: Diva Perss.

Monk. (2001). Psikologi Perkembangan Pengantar Dalam Berbagai Bagiannya. Yogyakarta: Gadjah Mada University Perss.

Naistadt, I. (2006). Jangan Takut Ngomong, Strategi Agar Berani Berbicara Di Depan Umum. Jakarta: Gramedia Pustaka.

Nuraeni, D. (2010). Hubungan Antara Kepercayaan Diri Dengan Komunikasi Interpersonal Pada Siswa Kelas XII \& XIII Di SLTP 1 Lumbang Pasuruan, Skripsi, Fakultas Psikologi Universitas Islam Negeri Maulana Malik Ibrahim Malang.

Olii, H. (2010). Public Speaking. Jakarta: Indeks.

Program Studi Psikologi Islam. (2013). Pedoman Penyusunan Skripsi Program Studi Psikologi Islam Edisi Revisi.
Rahayu, R. (2012). Hubungan Antara Kepercayaan Diri Dengan Komunikasi Interpersonal Pada Mahasiswa Fakultas Kesehatan Masyarakat Universitas Muhammadiyah Aceh di Banda Aceh, Jurnal, Vol 2, No 1, Fakultas Psikologi Universitas Islam Negeri Maulana Malik Ibrahim Malang.

Rakhmat, J. (2013). Psikologi Komunikasi. Bandung: PT Remaja Rosdakarya.

Reza, I. F. (2016). Penyusunan Skala Psikologi Memahami Manusia Secara Empiris. Palembang: Noer Fikri.

Sabati, F. (2010). Hubungan Antara Tingkat Berpikir Positif Dengan Kecemasan Komunikasi Fakultas Psikolgi UIN Jakarta, Skripsi, Fakultas Psikologi Universitas Islam Negeri Syarif Hidayahtullah.

Sarwono, S. (2010). Pengantar Psikolgi Umum. Jakarta: PT. Raja Grafindo Persada.

Semiun, Y. (2006). Kesehatan Mental 1. Yogyakarta: Kanisus.

Shihab, M. Q. (2002). Tafsir Al-Misbah: Pesan, Kesan, dan Keserasian AlQur'an Volume 12. Jakarta: Lentera Hati.

Shihab, M. Q. (2002). Tafsir Al-Misbah: Pesan, Kesan, dan Keserasian AlQur'an Volume 15. Jakarta: Lentera Hati.

Sugiyono. (2012). Metode Penelitian Pendekatan Kunatitatif, Kualitatif, $R \& B$. Bandung: Alpabeta.

Sujarwo, S. (2010). Diktat Kuliah Statistik Psikologi Jurusan Psikologi Islam.

Sulistyowati. (2015). Kamus Lengkap Bahasa Indonesia. Cv Buana Raya.

Walgito, B. (2003). Psikologi Sosial Suatu Pengantar. ANDI.

Wijaya, B. P. (2015). Buku Sakti Mahir Pidato. Yogyakarta: Second Hope.

Zaini, S. (1992). Penyakit Rohani dan Pengobatannya. Jakarta: Kalam Muliah. 